\title{
Explanation and analysis of localization approaches of academic humanities curriculum from the perspective of Iranian education
}

\author{
Yadolah Esfandiyaritit \\ Shahed University, Tehran, Iran \\ Soolmaz Nourabadiii(D) \\ Shahed University, Tehran, Iran
}

\begin{abstract}
In recent years, the evolution of education and curriculum has been one of the most important topics in educational circles. This implies that programs implemented in education for various reasons have not fully achieved the goals set. One of reasons for this is to "disregard localization in curriculum". Curriculum studies are among disciplines that can play an important role in influencing humanities curriculum planning process. But lack of a suitable indigenous curriculum template has made it increasingly reliant on foreign sources and imported and translated terms are used in abundance that has been led to little attention to customs, culture, social, economic and political conditions of society. Although Iranian culture and civilization originates from the fullest range of divine teachings, the educational system has failed to provide an appropriate educational model that is appropriate to cultural conditions throughout the country. A descriptive-analytical approach has been used to answer this question. The findings suggest that in order to change the humanities curriculum into an academic system, the curriculum needs to benefit from its rich Iranian culture and civilization in addition to applying the experiences of other countries and even goes a step further and introduce to the world a pattern arising from Iranian culture and civilization.
\end{abstract}

\section{Keywords}

Localization. Curriculum. Humanities. Iranian Culture and Civilization. Academic System.

\section{Explicação e análise das abordagens de localização do currículo acadêmico de ciências humanas na perspectiva da educação iraniana}

\begin{abstract}
Resumo
Nos últimos anos, a evolução da educação e do currículo tem sido um dos tópicos mais importantes nos círculos educacionais. Isso implica que os programas implementados na educação por várias razões não atingiram completamente os objetivos estabelecidos. Uma das razões para isso é "desconsiderar a localização no currículo". Os estudos curriculares estão entre as disciplinas que podem desempenhar um papel importante na influência do processo de planejamento curricular das ciências humanas. Porém, a falta de um modelo de currículo indígena adequado o tornou cada vez mais dependente de fontes estrangeiras e os termos importados e traduzidos são usados em
\end{abstract}

Educ. Form., Fortaleza, v. 5, n. 3, p. 1-13, set./dez. 2020

DOI: https://doi.org/10.25053/redufor.v5i15set/dez.3349

https://revistas.uece.br/index.php/redufor/index 
abundância, o que tem levado a pouca atenção às alfândegas, cultura, condições sociais, econômicas e políticas da sociedade. Embora a cultura e a civilização iranianas sejam originárias de toda a gama de ensinamentos divinos, o sistema educacional falhou em fornecer um modelo educacional adequado às condições culturais de todo o país. Uma abordagem analítico-descritiva foi usada para responder a essa pergunta. As descobertas sugerem que, para transformar o currículo de humanidades em um sistema acadêmico, o currículo precisa se beneficiar de sua rica cultura e civilização iraniana, além de aplicar as experiências de outros países e até dar um passo adiante e introduzir no mundo um padrão decorrente da cultura e civilização iranianas.

\title{
Palavras-chave
}

Localização. Currículo. Ciências humanas. Cultura e civilização iraniana. Sistema acadêmico.

\section{Explicación y análisis de los enfoques de localización del currículo académico de humanidades desde la perspectiva de la educación iraní}

\begin{abstract}
Resumen
En los últimos años, la evolución de la educación y el currículum ha sido uno de los temas más importantes en los círculos educativos. Esto implica que los programas implementados en educación por diversas razones no han logrado completamente los objetivos establecidos. Una de las razones para esto es "ignorar la localización en el currículo". Los estudios curriculares se encuentran entre las disciplinas que pueden desempeñar un papel importante en la influencia del proceso de planificación curricular de las humanidades. Pero la falta de una plantilla de currículum indígena adecuada la ha hecho cada vez más dependiente de fuentes extranjeras y los términos importados y traducidos se utilizan en abundancia y se ha prestado poca atención a las costumbres, la cultura, las condiciones sociales, económicas y políticas de la sociedad. Aunque la cultura y la civilización iraníes se originan en la más amplia gama de enseñanzas divinas, el sistema educativo no ha podido proporcionar un modelo educativo apropiado para las condiciones culturales en todo el país. Se ha utilizado un enfoque descriptivoanalítico para responder esta pregunta. Los resultados sugieren que, para cambiar el plan de estudios de humanidades en un sistema académico, el plan de estudios debe beneficiarse de su rica cultura y civilización iraníes, además de aplicar las experiencias de otros países e incluso ir un paso más allá e introducir al mundo un patrón derivada de la cultura y la civilización iraníes.
\end{abstract}

Palabras clave

Localización. Currículum. Humanidades. Cultura y civilización iraníes. Sistema académico.

\section{Introduction}

Undoubtedly, curricula in higher educational systems play a key and decisive role in success or failure of universities. The curriculum mirrors the whole view of progress and 
reflects how universities are responsive to changing societal needs. Given the tremendous innovations and changes taking place in various fields, the responsibility of documenting the findings and disseminating and promoting them in the form of well-organized and structured curricula is responsibility of universities. Unfortunately, despite the importance of curricula in universities, their attention is not sufficient and effort required to review, evaluate, modify and correct them is not on the agenda (STARK, 1997).

It should be known that the academic curriculum is very sensitive, delicate and complex process. Addressing academic curriculum requires individuals be very sensitive to the science set in which the project is to be implemented; Be aware of abilities, interests, and priorities of students for whom the program is designed, and be aware of up-to-date knowledge and developments. They also identify resources and facilities available to them and have ability and practical knowledge to research, teach, learn and evaluate. Thus, the curriculum model in higher education will be successful if it is present among participants in curriculum process (FATHI VAJARGAH, 2006).

The goals of academic curriculum are derived from the study of culture, higher education functions, social services and curriculum (SERAJl et al., 2007) and curricula are the most important component of any country's higher educational system. Paying attention to the goals and missions of "Ministry of Science, Research and Technology" show that some of them include deepening and expanding sciences, education, human values and enhancing artistic and aesthetic manifestations of scientific heritage of Iranian civilization, providing specialist human resources and they development in country, active participation in policy-making process of education and development system of the country's human resources in order to establish the necessary coordination between programs of different levels of education of country as well as to contribute to promotion of Islamic culture, ethics and spirituality in academic community (SECRETARIAT OF SUPREME COUNCIL OF CULTURAL REVOLUTION, 2008). This reflects attention of policymakers in field of education to national identity. Therefore, to achieve these goals, there is a need to evaluate absence of national identity components in curricula of universities and higher educational institutions in order to explain present status and plan to achieve desired status.

The "Localization" of curriculum is basically a policy that guides frameworks of educational and curriculum planning. The need to pay attention to this problem is not 
limited to higher education or humanities, but to all essential aspects of curricula, even the prospect of developing the country. Given the goals outlined in outlook document as well as the underlying emphasis on localization of higher education and lack of pure selfabsorption against theories and content outlined in West or East, the sensible aspects of these two processes are fundamental and seemingly at odds with each other needs attention. There is always an exaggeration in this path or a lack of attention to infrastructures and knowing the basic components of localization or globalization causes misunderstanding and emphasis on one and the other (RAFIEEPOUR, 2002).

Considering the importance of curriculum to policymakers in higher education and its sensitivity and complexity; and emphasizing the evolving document on curriculum localization in the face of globalization and its consequences, as well as capabilities, interests, and priorities of Iranians students and their religious beliefs and cultural values need to develop a program that consciously uses the patterns and methods of others and adapts them to conditions of indigenous community in addition to enhancing and reinforcing indigenous methods or knowledge link alien with indigenous knowledge and conditions lead to their comprehensive development, which in recent years, the curriculum development document has been communicated to all universities in the country. However, this sensitivity to humanities is greater because of its nature.

According to points that mentioned in this article, localization does not mean to ignore all human experience of the West, rather, its rules and theories must be weighed and accepted if they are adapted to native features. Naturally, that part of existing sciences that does not conflict with our religious-cultural concepts is acceptable, and that part which conflicts with our Iranian-Islamic nature is refined by refining and adapting to religious and rational teachings. In order to localize humanities curriculum; it is necessary to take into account the cultural requirements and social conditions of society, along with beliefs. In this research, the curriculum is intended to be the academic curriculum of the humanities, which is designed, implemented and evaluated in Islamic Iranian universities. Given the little researches in the field of localization and curriculum as well as the changes that have taken place over the years in the subject of academic humanities courses; the necessity of present study becomes clear. In particular, in the Iranian higher educational system, course titles play an important role in curriculum design and implementation. 


\section{Research method}

The research method in this article is a descriptive-analytical one. Therefore, the present study is a qualitative one with emphasis on processes and understanding of their interpretation. Therefore, in order to elucidate the nature and opportunities arising from patterns of localization approaches of curriculum, tried to use the most important theories in this field as well as considering the social, cultural and scientific contexts of Iran.

\section{Findings}

In the third millennium, the countless challenges such as the rapid growth of globalization and collapse of communication boundaries, spread of information technology, global information exchanges, economic growth of knowledge and research, increasing demand for global development, and national and international competitiveness have led to constant and fundamental changes in educational systems. Accordingly, policymakers and officials are seeking to reform educational systems, especially higher educational system, to prepare future leaders to meet the challenges of new age. In the face of this vibrant and full of motion environment, if the curricula outlined in each country's development programs, their national and indigenous values and frameworks as tree roots are deeply held in belief and acceptance of their nextgeneration. Undoubtedly, in this turbulent path, they become confused and may forget about the socialization of their cultural and global identity. Therefore, education, especially in humanities, has broadened the scope of all aspects of people's lives, directly or indirectly, and has changed the social, economic, cultural, and political life of people. Therefore, it is essential to know the perspectives outlined in development programs and upstream documents in educational programs and to pay attention to the goals outlined in educational programs. Given that in perspective of Islamic Republic of Iran, in 2025 Iran should be the first educational hub in the region, also given the emphasis on localization in various sciences, and especially in academic humanities, the importance of globalization and the need for localization in education are aspects that should not be neglected (GHASEMPOUR DEHAGHANI; LIAGHATDAR; JAFARI,

Educ. Form., Fortaleza, v. 5, n. 3, p. 1-13, set./dez. 2020 
2011). The following points out approaches and orientations that have emerged in the world to phenomenon of globalization.

The discussion of national and global identity and the question of persistence or continuity of national identities in the course of globalization and internationalization are other problems that have been raised following the phenomenon of globalization. Identity is "the process of meaning-making based on one cultural attribute or an interrelated set of cultural attributes that give priority to other semantic resources" (CASTELLS, 2005). In other words, national identity is "[...] a combination of attitudes, feelings, and perceptions of elements of socio-cultural affiliation that foster social cohesion and form part of one's identity" (BRANCH; TAYAL; TRIPLETT, 2008). There are different views on the phenomenon of globalization and the problem of preserving or removing national identity. Some believe that the move towards globalization has negative effect on national and local identity. Another group believes that globalization has no effect on global integration and elimination of national identity. The third group argues that the revolution in communications is fueling greater ethnic-cultural awareness. For this group, globalization has always involved the coherence and interconnection of two phenomena that are conventionally called "Global" and "Local". In this respect, they prefer the term "Localization Globalization” (GACEL, 2005).

In addition to above theories, which suggest that people's orientation is related to consequences and effects of globalization and internationalization on national and global identity, there are other theories that suggest orientation of some educational systems in relation to focus level on indigenous knowledge, the national identity of global knowledge and global identity. These theories have been put forward by Cheng (2004) and their analysis shows what policies can be adopted by educational systems based on each of these theories regarding the phenomenon of globalization and indigenous theory. What are their strengths and weaknesses in curriculum and what are the strengths and weaknesses of educational system in general and what are the outcomes of that system? In Cheng's (2000) research, various theories of localism versus globalization are discussed, which are explained in following.

Tree theory: Many Asian countries, such as China, India, Japan, Thailand, Korea, which have rich civilizational backgrounds, have made the most of their efforts to meet their cultural and national traditions in the face of challenge to maintain 
globalization. They often use tree theory to expand their local knowledge in the context of globalization, especially in education.

The underlying assumption of this theory is that the process of local and indigenous knowledge development must be rooted in local values and traditions in order to attract native knowledge to global system while promoting its indigenous knowledge on a global scale. Therefore, the spread of local knowledge in global education requires cultural roots and indigenous identity. As a result, curricula must be based on national values and identities, but have the latest technical knowledge to support the growth of their local and indigenous communities. This is the same point that has been emphasized in Islam and valuable words of Holy Prophet of Islam. Choosing and paying attention to world knowledge must also be based on rational and critical thinking because otherwise it will not only grow indigenous knowledge but will, as a strong poison, drain these cultural roots.

Crystal Theory: Some countries may be worried that they may completely lose their identity and indigenous values in the face of this flood. Therefore, they prefer to cultivate aspects of their local knowledge and resist globalization. This theory holds that the key is indigenous seeds are necessary for reflecting and gathering global knowledge. According to this theory, curriculum design should be based on identification of basic needs and values as primary seeds of absorption of knowledge and global education resources. What is also evident in this theory is a complete lack of self-esteem and lack of attention to cultural perceptions and value of local community.

Bird Cage Theory: The basic hypothesis of this theory in the face of globalization and narrowing of communication and information boundaries that have always been the concern of local politicians and officials that is how they protect themselves against the massive volume of global science and technology. The theory holds that the process of local knowledge development can accommodate global knowledge and resources, but at the same time it should strive to utilize global knowledge in consistent and specific format for benefit of indigenous knowledge development. This means that expanding indigenous knowledge on global scale requires frameworks for refining input knowledge. That is, attention to global dimensions should not have a negative effect on local knowledge development. In globalization of education, drawing clear ideological policies and social criteria is crucial in designing curricula and adopting 
education policies. Clearly, indigenous and national loyalty should be at the core of any education planning at different levels. The consequences of learning must be to nurture indigenous peoples with critical perspectives so that they will not be overwhelmed by the critique of global knowledge. This is the fundamental point that has been emphasized many times in Holy Quran that you accept rational discourse.

DNA Theory: The Contemporary history of some Asian countries have undertaken countless reforms and innovations to refine its inhumane cultural traditions and structures and to try to refine it with new ideas, specially Western ones. This theory emphasizes this shift and modification, in a way that replaces key and useful components of global knowledge with inappropriate process. But the important point in this theory is to recognize what needs to change.

Fungal Theory: Due to various geographical, economic, and historical causes, some countries may be heavily dependent on other countries, and accordingly their global knowledge selection and refinement may be based on these special conditions. This kind of approach is applicable to small countries that do not have a rich identity and, instead of building on their own indigenous knowledge, find it from a time-lapse and specific development of global knowledge. As a result, the curriculum should be aimed at helping learners move on to empowering local knowledge by identifying and learning global knowledge that, like an umbrella, casts a shadow over indigenous knowledge. In this approach that proposed by Cheng (2004), no new points are added to previous approaches, since identity and indigenous values; although are still emphasized less prominent than before.

Amoeba Theory: Some countries that do not have rich cultures and backgrounds may not have much interest in preserving what is known as indigenous values and cultural assets. What is most important for this kind of attitude is the change in line with global developments and economic stability in international competition. The lack of sensitivity to particular position and sheer attention to global developments have provided basis for harmonization of global knowledge in local communities with this kind of attitude. The notable point in this theory is disregard for values and cultural identity of indigenous community. As such, it lacks any economic and refinement thinking that fits in with specific values and ideologies (BIDOKHT; HOSSEINPOUR, 2010). 


\section{Conclusion}

With expansion of globalization approach and its consequences, which at times have nothing to do with the culture and beliefs of society; planners in some countries developed an approach called "Localizing Approach" that addresses both local and global knowledge and it accepts the part that is in line with culture and belief values of society and re-engineering the part that does not conform and adapts to social and cultural conditions of its society. In this approach, experts in higher educational system are alert and active, not accepting what is produced in Western societies with a blind eye; rather, they examine them with open eyes and speak in accordance with the values of community and their religious beliefs. In our country for many years, localization of curriculum, specially humanities curriculum in universities has been emphasized.

Another point is that Western methodology is purely empirical-inductive, while we also believe in deductive science and believe in cognition. In the humanities that existed in West in eighteenth century onwards, there is relativist positivist, instinctual anthropology, materialist ontology, and this is different from our view of humanities. Our cosmology is both material and abstract, and our view of the world, both the world and the hereafter, and our view of man in addition to instinct, is based on nature, and although accept some relative knowledge, our knowledge is not relativistic. These produce different results. Therefore, the different theoretical foundations we have adopted, in contrast to theoretical foundations currently adopted in humanities and social sciences, have in fact produced two different sciences and, in a sense, have contrasted two scientific discourses. Experts, therefore, believe that it is necessary to have a proper look at Islamic anthropology to localize humanities.

It pointed out that one of the approaches in localization theory of humanities curriculum is tree theory, the main premise of which is that the process of local and indigenous knowledge development must be rooted in local values and traditions in order to be able to absorption of useful and appropriate resources from global knowledge system will enable its indigenous knowledge to grow globally. Some countries may be worried that they will lose their indigenous values as a result of globalization. Therefore, they prefer to develop aspects of their local knowledge and resist globalization, thus using crystal theory. The birdcage theory holds that the process of local knowledge 
dissemination can accommodate global knowledge and resources, but at the same time it must strive to utilize universal knowledge in a fixed and specific format for benefit of indigenous knowledge development. This means that expanding indigenous knowledge on global scale requires frameworks for refining input knowledge. DNA theory emphasizes displacement and modification. In a way that replaces the inadequate process of key and useful components of global knowledge. But small countries that do not have a rich identity apply fungal theory and, instead of building up their own indigenous knowledge, find it through a time-lapse and specific development of global knowledge that learners identify and learn with global knowledge that like an umbrella over indigenous knowledge, they move to empower indigenous knowledge. Amoebic theory may be used in some countries that do not have rich cultures and backgrounds and may not be very committed to preserving what is known as indigenous values and cultural assets. What is most important for this kind of attitude is the harmonious change in global competition and economic stability in international competition.

Now the question is which of the above approaches can be better and more compatible with cultural, religious, economic, social, political and geographical conditions of Islamic Iran?

Looking at the theories related to localization orientations, we come to conclusion that each of the approaches and theories put forward for localization of curriculum, based on importance of indigenous knowledge, universal knowledge, believes in national identity and global identity; it has specific implications and outcomes in society. Each of these theories is a range or type of curriculum theories that can help policymakers and curriculum planners in educational institutions to better understand the positive and negative consequences of their planning. Therefore, it is preferable for each of these approaches in process of localizing the curriculum based on the importance of indigenous knowledge and national identity face to the world knowledge and identity. For example, if the curriculum localization approaches in our society's educational system focus on theories of Fungi or Amoeba or DNA, it is natural to focus on global knowledge and its use in curriculum design. This orientation leads to a disregard for development of national knowledge, national identity, and cultural and social capital. If the education of our society is based on birdcage approach, it is only natural that the sheer use of national knowledge will be focus of attention and that educational centers will need to focus solely on cultural 
and social backgrounds for development of national knowledge. They need the knowledge of the world and cannot take advantage of opportunities of globalization and internationalization and even get hurt. The Crystal approach, as it focuses only on one particular aspect of its national culture and civilization and knowledge, cannot encompass all aspects as it deserves rich Iranian culture and civilization. Therefore, we, who have rich civilizational backgrounds, must have some kind of curriculum and education that will benefit from the sharing of global knowledge while also enhancing indigenous knowledge. In fact, a two-way growth that preserves both our rich cultural heritage and the pinnacle of global knowledge. This can be achieved by using Tree theory to expand local knowledge in the context of globalization. In sum, since the academic curriculum is of particular sensitivity, finesse, and complexity, by adding the localization approach of the curriculum, this complexity and sensitivity are doubled. Because the university must pay more attention to the curriculum localization approach in one hand, and on the other hands, it is imperative that the university be able to compete with the world's universities, so it must be up-to-date. In fact, in order to achieve comprehensive growth and development, while using the patterns and methods of others and adapting them to the indigenous conditions of society, in addition to updating their programs and reinforcing indigenous approaches, be able to link foreign knowledge with native knowledge. In this case, the task becomes more complex and sensitive. This study has explored and analyzed the nature of localization with the view of Islamic Iran education in humanities curriculum of academic system, has described strengths and weaknesses of current situation and has identified barriers. It is important to recognize that not paying attention to this problem can lead to problems with the localization of the academic curriculum and take the necessary effectiveness out of it and cause irreparable damage in the long run. Therefore, it is important that humanities specialists and planners in the academic system of our country pay close attention to this important point.

\section{References}

BRANCH, C. W.; TAYAL, P.; Triplett, C. The Relationship of ethnic identity and ego identity status among adolescents and young adults. International Journal of Intercultural Relations, v. 24, n. 6, p. 777-790, 2008. 
CASTELLS, M. Goolbal goverance and golbal politics. Academic Research Library, v. 38, n. 1, p. 9-16, 2005.

CHENG, Y. C. Fostering local knowledge and human development globalization of education. International Journal of Management, v. 18, n. 1, p. 7-24, 2004.

CHENG, Y. C. ACMI, Triplization paradigm for reforming education in the new millennium. International journal of Educational management, v. 14, n. 4, p. 156-174, 2000.

FATHI VAJARGAH, K. Curriculum and developing the lesson plan in higher education. Tehran: Korush Institute, 2006.

GACEL, J. A. The internationalization of higher education: a paradigm for global citizenry. Journal of Studies in International Education, v. 9, n. 2, p. 121-136, 2005.

GHASEMPOUR DEHAGHANI, A.; LIAGHATDAR, M. J.; JAFARI, S. E. An analysis of the localization and internationalization of the University Curriculum in the age of globalization. Journal of Cultural Research, p. 10-15, 2011.

HOSSEINI BIDOKHT, M.; HOSSEINPOUR, S. Regional Conference on Localization of Higher Education Progress Model. The Islamic Azad University of Sanandaj Branch, p. 54-66, 2010.

RAFIEEPOUR, F. Obstacles to scientific growth in Iran. Tehran: Sahaabi, 2002.

SECRETARIAT OF SUPREME COUNCIL OF CULTURAL REVOLUTION.

Comprehensive Scientific Map of the Country. 2. ed. Tehran: Secretariat of Supreme Council of Cultural Revolution, 2008.

SERAJI, F. et al. Virtual University Curriculum Design. Journal of Curriculum Studies, v. 2, p. 79-95, 2007.

STARK, J. S. et al. Shaping the college Curriculum Academic Plans in Action. 20-year Perspective Document of Iran in 2025 horizon. 1997.

\footnotetext{
Yadolah Esfandiyari, Shahed University, Department of Educational Sciences, Faculty of Humanities iDhttps://orcid.org/0000-0003-0348-2247

Associate Professor at Shahed University, Tehran, Iran. Research on the curriculum and its elements in the higher education system.

Authorship contribution: Developed the research and wrote the text.

E-mail: esfandyari3757@gmail.com
}

Educ. Form., Fortaleza, v. 5, n. 3, p. 1-13, set./dez. 2020

DOI: https://doi.org/10.25053/redufor.v5i15set/dez.3349

https://revistas.uece.br/index.php/redufor/index 
Soolmaz Nourabadi, Shahed University, Department of Educational Sciences, Faculty of Humanities ii(Dhttps://orcid.org/0000-0003-0229-2329

Assistant curriculum teacher, Department of Educational Sciences, Shahed University, Tehran, Iran. Research on curricula in Iran's higher education system.

Authorship contribution: Guided the writing of the entire article and the research.

E-mail: nourabadi@shahed.ac.ir

Responsible publisher: Lia Machado Fiuza Fialho

Ad hoc experts: Cristine Brandeburg and Karla Angélica Silva do Nascimento

\section{How to cite this article (ABNT):}

ESFANDIYARI, Yadolah; NOURABADI, Soolmaz. Explanation and analysis of localization approaches of academic humanities curriculum from the perspective of Iranian education. Educ. Form., Fortaleza, v. 5, n. 3, p. 1-13, 2020. Available at: https://revistas.uece.br/index.php/redufor/article/view/3349.

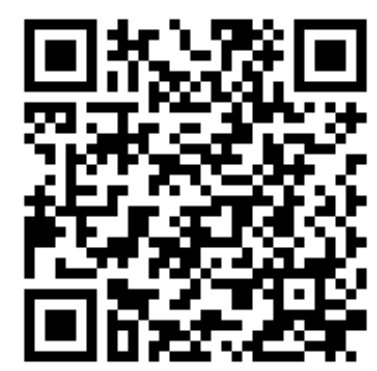

Received on June $1^{\text {st }}, 2020$.

Accepted on June $15^{\text {th }}, 2020$.

Published on July $26^{\text {th }}, 2020$. 